ISSN 1392-3196 / e-ISSN 2335-8947

Zemdirbyste-Agriculture, vol. 100, No. 2 (2013), p. 179-184

DOI 10.13080/z-a.2013.100.023

\title{
The effect of strong microwave electric field radiation on: (1) vegetable seed germination and seedling growth rate
}

\author{
Audrius RADZEVIČIUS ${ }^{1}$, Sandra SAKALAUSKIENE ${ }^{1}$, Mindaugas DAGYS ${ }^{2}$, \\ Rimantas SIMNIŠKIS ${ }^{2}$, Rasa KARKLELIENE ${ }^{1}$, Česlovas BOBINAS ${ }^{1}$, Pavelas DUCHOVSKIS ${ }^{1}$ \\ ${ }^{1}$ Institute of Horticulture, Lithuanian Research Centre for Agriculture and Forestry \\ Kauno 30, Babtai, Kaunas distr., Lithuania \\ E-mail: a.radzevicius@1sdi.lt \\ ${ }^{2}$ Center for Physical Sciences and Technology \\ Go tauto 11, Vilnius, Lithuania \\ E-mail: dagys@pfi.lt
}

\begin{abstract}
The effect of high power microwave (HPM) irradiation on seed germination and seedlings was evaluated. Vegetable seeds were subjected to HPM irradiation. The main focus was on the thermal heating elimination during seeds irradiation. For that reason short high frequency microwave pulses were used. The study object was seeds of different harvest years (2000, 2003 and 2008) of radish (Raphanus sativus L.) variety 'Babtų žara', tomato (Lycopersicon esculentum Mill.) variety 'Viltis', carrot (Daucus sativus Rohl.) variety 'Vaiguva' and tomato (Lycopersicon esculentum Mill.) variety 'Red Cherry' (seeds harvested in 1980). In the first experiment, all seeds were exposed to microwaves at $9.3 \mathrm{GHz}$ frequency for $10 \mathrm{~min}$. In the second experiment, carrots 'Vaiguva' seeds (11 years-old) were exposed to microwaves at $9.3 \mathrm{GHz}$ frequency for 5 and $20 \mathrm{~min}$ and exposed to 2.6 and 5.7 $\mathrm{GHz}$ microwaves for $10 \mathrm{~min}$. To establish microwave effect on seedling growth rate, tomato, carrot and radish seeds harvested in 2008 were exposed to microwaves at $9.3 \mathrm{GHz}$ frequency for $10 \mathrm{~min}$. It was established that 11 year-old radish seeds exposed to $9.3 \mathrm{GHz}$ microwaves had higher germination as compared with non-irradiated seeds. HPM increased radish germination energy by $6 \%$ in seeds harvested in 2003. HPM exposure significantly increased the germination energy and germination of 8 year-old carrot seeds. The highest carrot seed germination was established at $9.3 \mathrm{GHz}$ microwave frequency under $5 \mathrm{~min}$ exposure. Seed exposure to HPM (9.3 GHz) had a significant positive effect on dry weight of tomato seedling shoots and on tomato and radish seedling height, but it had negative influence on carrot seedling height. Seed irradiation with HPM $(9.3 \mathrm{GHz})$ had a significant positive effect on the amount of chlorophyll $a$, chlorophyll $b$, chlorophylls $a+b$ and carotenoids in tomato seedlings' fresh mass, but the opposite effect was determined in carrot seedlings' fresh mass.
\end{abstract}

Key words: Daucus sativus, irradiation, Lycopersicon esculentum, photosynthetic pigments, Raphanus sativus.

\section{Introduction}

Microwaves are part of the electromagnetic spectrum and are considered to be that radiation ranging in frequency from 300 million cycles per second $(300 \mathrm{MHz})$ to 300 billion cycles per second $(300 \mathrm{GHz})$, which correspond to a wavelength range of $1 \mathrm{~m}$ down to $1 \mathrm{~mm}$. This nonionising electromagnetic radiation is absorbed at molecular level and manifests as changes in vibrational energy of the molecules or heat (Banik et al., 2003).

A wide-ranging review of the effects of various forms of externally applied electrical energy upon plants and organisms is presented. Most of the papers describe microwave experiments using $12.25 \mathrm{~cm}$ wavelength which corresponds to a frequency of $2450 \mathrm{MHz}$. This is one of the frequencies allocated, by international agreement, to microwave power devices for domestic and industrial applications. So we can find information about thermal influence on biological objects using microwave ovens. Also, it is very important to investigate the influence of high power microwave (HPM) pulses on the plants and their seeds trying to distinguish between heating and direct influence of strong electric field on them. There is very little information about the effect of HPM pulses on the various agricultural crops.

The existence of specific (non-thermal) biological effects of extremely high power microwave pulses still remains discussable. The fact that extremely high power microwave can certainly produce a thermal effect makes it technically difficult to discriminate its possible specific effect in experiments (Pachomov, 1998; Tylkowska et al., 2010). Scientists made calculations and came to the conclusion that the thermal effect of short microwave pulses, when hygienic limits are not exceeded, is not able to make any chemical or structural changes in the biological tissue, even if a worst assumption of $100 \%$ absorption of a maximum (allowed by International Commission for Non-Ionizing Radiation Protection) pulsed energy in a thin protein monomolecular layer within an extremely short time is considered. In addition, 
there is no physical cause for expectation of another effect of pulsed high frequency fields than the thermal effect (Šistek, 2002; Racuciu, Miclaus, 2007).

The exact biochemical processes by which microwaves could affect the functioning of living organisms are not very well understood and the mechanism may vary depending upon the amplitude of the field and its frequency and, in the general case, on the duty cycle (Monteiro et al., 2008; Aladjadjiyan, 2010). Yanenko and co-workers (2004) report that among physical methods for the pre-sowing treatment of seeds electromagnetic irradiation deserves special attention. The frequencies of the cell membrane vibrations of biological objects lie in the mm-wave range. Mm-waves are known to be immanent to any living organism. The mm-wave irradiation of biological objects initiates resonant phenomena in living cells and has an overall positive impact on biological organisms (Aladjadjiyan, 2002; Yanenko et al., 2004).

Various experiments showed that HPM can affect plant growth and the prolonged exposure to microwave affects seed germination (Hamada, 2007; Aladjadjiyan, 2010; Salama et al., 2011). Oprica (2008) indicated that microwaves determined variations of catalase and peroxidase activities in Brassica napus depending on the microwave exposure time, age of the plants, and condition of seeds (germinated or non-germinated). It was noted that weak intensity of microwaves did not affect plant growth but increased doses slowed seed germination (Oprica, 2008). Ponomarev et al. (1996) studied the direct effect of electromagnetic radiation of the microwave range (wavelength $\lambda=1 \mathrm{~cm}$, irradiation time up to $40 \mathrm{~min}$ ) on the germination of cereals (winter and spring wheat, spring barley, oats). They established increased germination rate in all the tested seeds and reached optimal stimulating effect at $20 \mathrm{~min}$ exposure time.

The aim of our study was to evaluate the influence of different frequencies of high power microwave (HPM) pulses on vegetable seed germination and microwave (at 9.3 GHz frequency) effect on seedling growth rate.

\section{Materials and methods}

At the Centre of Physical Sciences and Technology, vegetable seeds were irradiated by high power microwaves (HPM) inside the waveguides in 2011. The experimental set-up is shown in Figure 1.

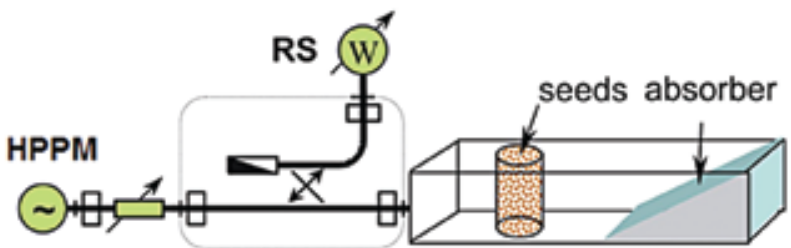

HPPM - a high power pulsed magnetron, RS - a resistive sensor applied as transmitted microwave power meter

Figure 1. Experimental set-up: microwave irradiation on vegetable seeds in waveguide

Special thin wall plastic containers for seed irradiation were used to maintain the uniformity of electric field distribution inside the waveguide. It is supposed that walls of cylindrical container are thin, the humidity of seeds is low, and therefore the electric field in the container, mounted in the middle of rectangular waveguide, is the same as in the empty waveguide, so can be calculated:

$$
E=\sqrt{\frac{2 z_{B} P}{a b}}, z_{B}=\frac{z_{0}}{\sqrt{1-(\lambda / 2 a)^{2}}},
$$

where $Z_{\mathrm{B}}$ is waveguide impedance, $Z_{0}=377 \Omega$ is free space impedance, $a$ and $b$ are rectangular waveguide dimensions, $\lambda$ is microwave wavelength.

Table 1 presents the maximum power and electric field level and radiation conditions on seeds in the waveguides.

Table 1. Maximum power and electric field of vegetable seed irradiation in the waveguides

\begin{tabular}{ccccc}
\hline Band & $\begin{array}{c}\text { Frequency } \\
\mathrm{GHz}\end{array}$ & $\begin{array}{c}\text { Waveguide } \mathrm{a} \times \mathrm{b} \\
\mathrm{mm}^{2}\end{array}$ & $\begin{array}{c}\text { Power } \\
\mathrm{kW}\end{array}$ & $\begin{array}{c}\mathrm{E} \\
\mathrm{kV} \mathrm{m}^{-1}\end{array}$ \\
\hline $\mathrm{S}$ & 2.6 & $72 \times 34$ & 100 & 226 \\
$\mathrm{C}$ & 5.7 & $40 \times 20$ & 100 & 316 \\
$\mathrm{X}$ & 9.3 & $23 \times 10$ & 80 & 606 \\
\hline
\end{tabular}

$\mathrm{S}, \mathrm{C}$ and $\mathrm{X}-\mathrm{a}$ strong microwave electric field band

Investigating the effect of microwave exposure, the seeds of vegetables were irradiated by HPM. The main focus was on the thermal heating elimination during seeds irradiation. For that reason short high frequency microwave pulses were used.

The study object was seeds of different harvest years (2000, 2003 and 2008) of radish (Raphanus sativus L.) variety 'Babtų žara', tomato (Lycopersicon esculentum Mill.) variety 'Viltis', carrot (Daucus sativus Rohl.) variety 'Vaiguva' and tomato (Lycopersicon esculentum Mill.) variety 'Red Cherry' (seeds harvested in 1980). In the first experiment, all seeds were exposed to microwaves at $9.3 \mathrm{GHz}$ frequency for $10 \mathrm{~min}$, where pulse duration was $4 \mu$ s and pulse repetition $-25 \mathrm{~Hz}$, electric field $-320 \mathrm{kV} \mathrm{m}^{-1}$. In the second experiment, in one treatment the seeds of carrot variety 'Vaiguva' (11 years-old) were exposed to microwaves at $9.3 \mathrm{GHz}$ frequency for 5 and $20 \mathrm{~min}$ at $322 \mathrm{kV} \mathrm{m}^{-1}$ electric field. In other treatment, the seeds were exposed to $2.6 \mathrm{GHz}$ microwaves at $241 \mathrm{kV} \mathrm{m}^{-1}$ electric field and to $5.7 \mathrm{GHz}$ microwaves at $329 \mathrm{kV} \mathrm{m}^{-1}$ electric field for $10 \mathrm{~min}$. In both cases pulse duration was $4 \mu$ s and pulse repetition $-25 \mathrm{~Hz}$. Control treatment was non-irradiated seeds. In order to establish HPM effect on seedling growth rate (shoot and root dry weight, plant height, hypocotyl length and height, leaf area, chlorophyll $a$, chlorophyll $b$, chlorophyll $a+b$ and carotenoids) tomato (variety 'Viltis'), carrot (variety 'Vaiguva') and radish (variety 'Babtų žara') 3 year-old seeds were irradiated by microwaves at $9.3 \mathrm{GHz}$ frequency for $10 \mathrm{~min}$, where pulse duration was $4 \mu \mathrm{s}$ and pulse repetition $-25 \mathrm{~Hz}$, electric field $-320 \mathrm{kV} \mathrm{m}^{-1}$. 14-day old seedlings were used for analysis and measurements.

Determination of seed germination. The seeds were germinated in Petri plates on filtered paper in a thermostat and stored at variable temperature. It means that higher temperature $\left(30^{\circ} \mathrm{C}\right)$ was maintained for a 6-hour period and for 18-hour period - temperature was lower $\left(20^{\circ} \mathrm{C}\right)$. Samples of 100 seeds each were repeated 4 times. Petri plates were ventilated every day by opening for a few seconds and optimum moisture content was maintained. Radish, carrot, tomato seed germination 
energy was observed after 3, 5 and 6 days, respectively. Germination of radish was determined after 7 days and that of carrots and tomatoes after 10 days. Seeds with normally developed rootlet (rootlet diameter was not less than the diameter of the seed) were counted.

Biometric measurments. Plant height, hypocotyl length and height were measured in $\mathrm{cm}$. Fresh mass was measured in g. Dry mass of roots and shoots of vegetable seedlings was evaluated by drying plants in a drying oven ("Venticell MBT", Czech Republic) at $105^{\circ} \mathrm{C}$ for $24 \mathrm{~h}$. Leaf area was measured by an automatic leaf area meter (“AT Delta-T Devices", England).

Determination of chlorophyll and carotenoids. The amounts of chlorophyll and carotenoids in fresh mass (FM) were determined by spectrophotometry in pure acetone extract (Gavrilenko, Zigalova, 2003), using a "Genesys 6" spectrophotometer ("Thermo Spectronic", USA).

The obtained data were processed using $M S$ Excel software (version 7.0) and statistical software Statistica 7 and ANOVA.

\section{Results and analysis}

Vegetable yield depends not only on the variety but also on seed quality. The main indicators of good seed quality are purity, germination and germination energy. According to the quality requirements for all seed categories, germination of radish should reach $80 \%$, carrots $-70 \%$, and tomatoes - at least $75 \%$ (Bobinas, 1999; Radzevičius et al., 2007). Already in the 1970's Crawford (1977) reported that microwaves can decrease seed germination. He examined the phytotoxic effect of $2450 \mathrm{MHz}$ radiation on the seeds of Trifolium and Medicago cultivars. All seeds showed a marked decrease in germination after treatment for 15-20 seconds. According to our results (Fig. 2), radish seeds (harvested in 2000) exposed to $9.3 \mathrm{GHz}$ microwaves had higher germination rate $(26 \%)$, but HPM had no effect on germination energy as compared with non-irradiated seeds $(16.7 \%)$.

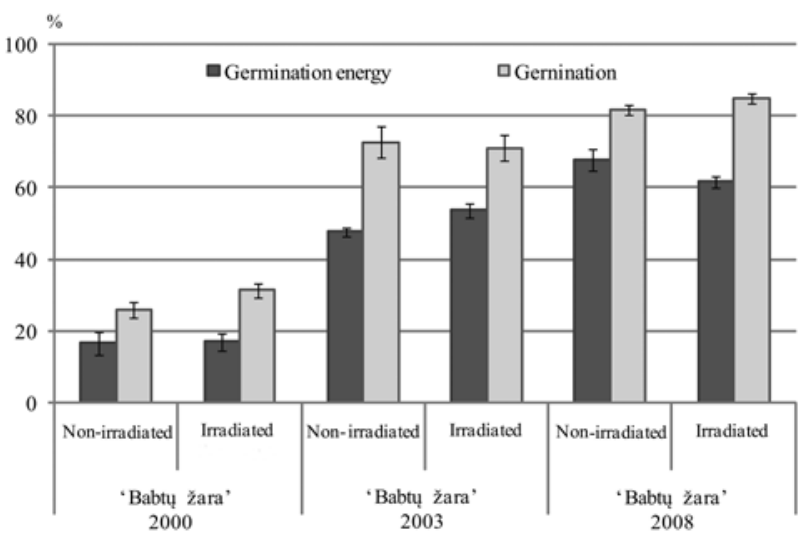

Figure 2. The effect of high power microwave (HPM) irradiation $(9.3 \mathrm{GHz})$ on germination rate and germination energy of radish seeds

Irradiation had no effect on the germination rate of radish seed (harvested in 2003 and 2008) (Fig. 2). HPM increased radish germination energy by $6 \%$ in the seeds harvested in 2003, but in the seeds harvested in 2008 there was determined a $6 \%$ decrease in germination energy. Non-thermal effects on seeds and biological objects are due to the direct interaction of the microwaves on molecules or tissue components, since particles seek to orient themselves within the electric field and minimize potential energy (Salles, 1999).

The data (Fig. 3) of this study showed significant increase in germination energy in irradiated tomato seeds harvested in 2003 and 2008 (15.3\% and $27.0 \%$, respectively) but irradiation had no effect on tomato germination rate as compared with the control treatments. HPM did not induce germination energy in the tomato (variety 'Viltis') seeds harvested in 2000, but irradiation increased their germination rate by $8.7 \%$. Meanwhile, seeds (harvested in 1980) of the variety 'Red Cherry' had lost their germination and microwave exposure did not induce biological processes. There is opposing information about microwave effect on seed germination. Monteiro and colleagues (2008) have reported about grass seed germination decrease under microwave irradiation. Studies on microwave field effect on the germination rate and the shoot growth rate showed that the microwave fields possibly retard the germination but the effect on the tubule growth is uncertain and the data from the ongoing experiments provided statistically meaningful results (Monteiro et al., 2008). While Ragha and co-workers (2011) suggest that high frequency stimulated seed germination for most of the investigated samples as compared to the control.

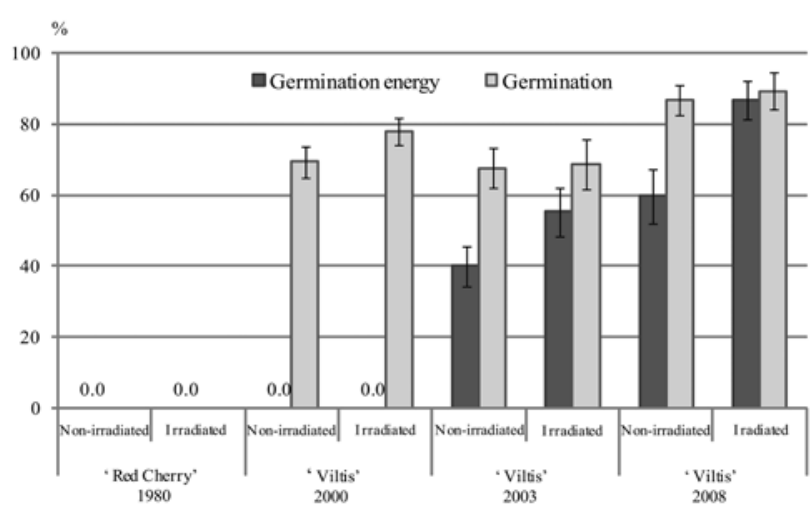

Figure 3. The effect of high power microwave (HPM) irradiation $(9.3 \mathrm{GHz})$ on germination rate and germination energy of tomato seeds

We evaluated the irradiation effect of $9.3 \mathrm{GHz}$ microwave frequency on the seeds of carrot variety 'Vaiguva' (Fig. 4) and found the highest germination rate $(19.3 \%)$ in the seeds harvested in 2008 and a $4.6 \%$ germination rate increase in the seeds harvested in 2003 as compared with non-irradiated.

Microwave exposure significantly increased the germination energy by $3.6 \%$ and germination rate by $11.0 \%$ in the carrot seeds harvested in 2003 . In this case, it was possible that carrot seed molecules might be lifted into the metastable state through the action of electric fields, e.g., when built into a membrane through the high electric field existing there. The high dipole moment of the metastable state implies in general its excitation to be coupled with excitation of homogeneous electric vibrations, i.e. giant dipole oscillations (Frohlich, 1975; Gorny et al., 2007). Evaluation of different HPM frequencies and different effects of irradiation time (Fig. 5) showed that the highest carrot seed germination 


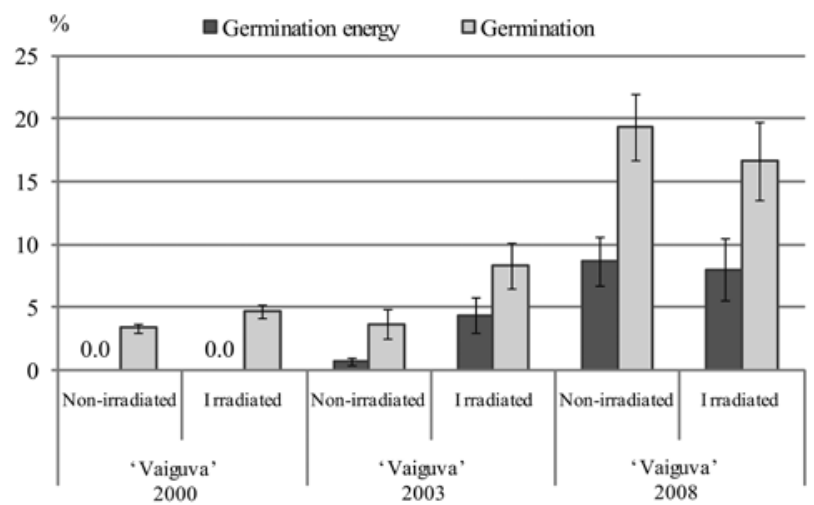

Figure 4. The effect of high power microwave (HPM) irradiation $(9.3 \mathrm{GHz})$ on the germination rate and germination energy of carrot seeds

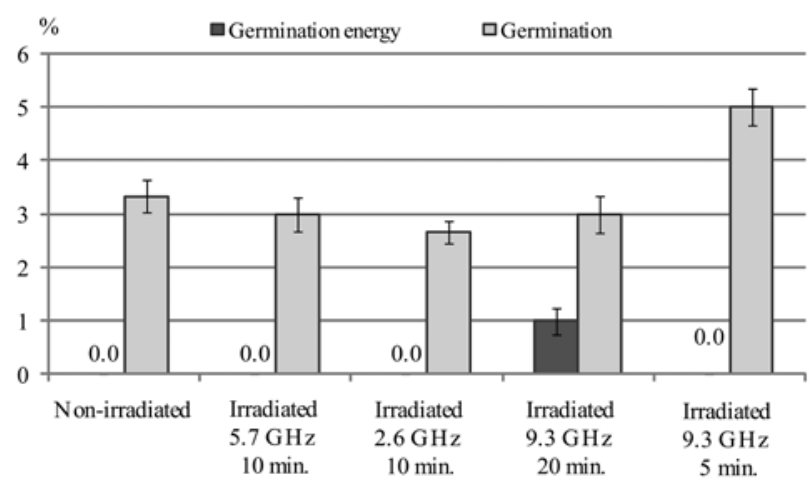

Figure 5. The effect of different high power microwave (HPM) irradiation frequency and time on carrot seeds

rate $5.0 \%$ was established at $9.3 \mathrm{GHz}$ microwave frequency under $5 \mathrm{~min}$ exposure. A 10-min exposure and $2.6 \mathrm{GHz}$ microwave frequency significantly reduced carrot seed germination by $0.6 \%$. Among other treatment combinations, significant differences were not detected. Various frequencies of HPM had different effect on carrot seed germination. Experiments with different electromagnetic fields' strengths on carrot seed were made in Lithuania in 2007. It was established that different strengths of direct electromagnetic field and exposure time had different effect on carrot yield, quality and seed germination dynamics (Stašelis, 2007).

Seed exposure to HPM $(9.3 \mathrm{GHz})$ had a significant positive effect ( $1.32 \mathrm{~g}$ ) on dry weight of tomato (variety 'Viltis') seedling shoots and significant negative effect on root dry mass $(0.87 \mathrm{~g})$ of tomato seedlings
(Table 2). Vegetable seedlings growth from irradiated seeds had no significant difference in hypocotyl height. Radish hypocotyl (grown from irradiated seeds) was twice as thick as that of radish grown from non-irradiated seeds. Results indicated that the seed irradiation had significant positive effect on the height of tomato (2.08 $\mathrm{cm})$ and radish $(1.76 \mathrm{~cm})$ seedlings, but it had negative influence on the height of carrot seedlings. Irradiated carrot seedlings were shorter $(1.0 \mathrm{~cm})$ as compared with non-irradiated. Seeds irradiation determined significantly higher assimilating area $\left(7.3 \mathrm{~cm}^{2}\right)$ in tomato seedlings and significantly lower assimilating area $(6.4 \mathrm{~cm})$ in carrot seedlings. Raga and co-workers (2011) observed that irradiation of seeds resulted in a significant increase in plant biomass, but admitted that the effect varied according to the plant species and their ecological adaptation. Other scientists found that direct effect of electromagnetic fields stimulates the development of tomato plants, irradiated tomato sprouts grew up higher, formed more leaves and accumulated more fresh mass (Stašelis et al., 2004). Hamada (2007) investigated different doses of microwaves on wheat and determined that irradiation increased root and shoot lengths also fresh mass in 14 days' old wheat seedlings.

Photosynthetic pigments are very important physiological indexes. In connection with photosynthesis productivity, the amount of photosyntetic pigments can be an evidence of stressors tolerance in plants (Salama et al., 2011; Samuoliené et al., 2012). Our results indicated, that seed exposure to HPM $(9.3 \mathrm{GHz})$ had significant positive effect on the amount of chlorophyll $a$ $\left(0.224 \mathrm{mg} \mathrm{g}^{-1}\right)$, chlorophyll $b\left(0.048 \mathrm{mg} \mathrm{g}^{-1}\right)$, chlorophylls $a+b\left(0.272 \mathrm{mg} \mathrm{g}^{-1}\right)$ and carotenoids $\left(0.082 \mathrm{mg} \mathrm{g}^{-1}\right)$ in tomato seedlings fresh mass (Table 3 ). The opposite effect was determined in carrot seedlings FM. Seed irradiation did not influence the amount of photosynthetic pigments in radish seedlings FM. Positive effect of HPM on photosynthetic pigment amount in wheat seedlings was reported by Hamada (2007). He admitted that chlorophyll $a / b$ and carotenoids ratios increased in 7 days' old seedlings, but they tended to diminish in 14 days' old seedlings as compared with non-irradiated seedlings. The possible explanation suggests a hypothesis about the absorption of the microwave radiation energy by the hydrogen or magnesium atom's electrons in the chlorophyll molecule. The energy absorbed is redistributed and it causes changes in the chlorophyll molecule (Aladjadjiyan, 2002).

Table 2. The effect of seed irradiation $(9.3 \mathrm{GHz})$ on the growth parameters of tomato, carrot and radish seedlings

\begin{tabular}{|c|c|c|c|c|c|c|c|c|c|c|c|c|}
\hline \multirow[b]{2}{*}{ Treatment } & \multicolumn{4}{|c|}{ Dry weight g } & \multirow{2}{*}{$\begin{array}{l}\text { Hypocotyl } \\
\text { height } \\
\mathrm{cm}\end{array}$} & \multirow{2}{*}{ STDEV } & \multirow{2}{*}{$\begin{array}{c}\text { Hypocotyl } \\
\text { thickness } \\
\mathrm{cm}\end{array}$} & \multirow[b]{2}{*}{ STDEV } & \multirow{2}{*}{$\begin{array}{c}\text { Plant } \\
\text { height } \\
\mathrm{cm}\end{array}$} & \multirow[b]{2}{*}{ STDEV } & \multirow{2}{*}{$\begin{array}{c}\text { Assimila- } \\
\text { ting } \\
\text { area } \\
\mathrm{cm}^{2}\end{array}$} & \multirow[b]{2}{*}{ STDEV } \\
\hline & Roots & STDEV & Shoots & STDEV & & & & & & & & \\
\hline Tomato $\mathrm{C}$. & 3.50 & 0.32 & 1.66 & 0.32 & 5.86 & 0.53 & 0.10 & 0.00 & 11.42 & 1.07 & 15.5 & 2.51 \\
\hline Tomato Ir. & 2.63 & 0.10 & 2.98 & 0.42 & 5.92 & 0.48 & 0.10 & 0.00 & 13.50 & 0.99 & 22.8 & 2.63 \\
\hline Carrots C. & 12.72 & 0.85 & 7.91 & 1.07 & 4.40 & 1.67 & 0.10 & 0.01 & 14.90 & 0.22 & 22.1 & 2.66 \\
\hline Carrots Ir. & 12.70 & 0.92 & 7.02 & 1.49 & 3.20 & 1.59 & 0.30 & 0.09 & 13.90 & 0.39 & 15.7 & 2.20 \\
\hline Radish C. & 5.47 & 0.68 & 5.20 & 0.49 & 2.16 & 0.19 & 0.74 & 0.11 & 12.70 & 0.66 & 101.5 & 5.68 \\
\hline Radish Ir. & 5.07 & 0.53 & 5.26 & 0.55 & 2.38 & 0.18 & 1.34 & 0.14 & 14.46 & 0.55 & 108.1 & 7.13 \\
\hline
\end{tabular}

STDEV - standard deviation, C. - control, non-irradiated, Ir. - irradiated seeds 
Table 3. The effect of seed irradiation $(9.3 \mathrm{GHz})$ on photosyntetic pigments in tomato, carrot and radish seedlings

\begin{tabular}{lcccccccc}
\hline Treatment & $\begin{array}{c}\text { Chlorophyll } a \\
\mathrm{mg} \mathrm{g}^{-1} \mathrm{FM}\end{array}$ & STDEV & $\begin{array}{c}\text { Chlorophyll } b \\
\mathrm{mg} \mathrm{g}^{-1} \mathrm{FM}\end{array}$ & STDEV & $\begin{array}{c}\text { Chlorophylls } \\
a+b \\
\mathrm{mg} \mathrm{g}^{-1} \mathrm{FM}\end{array}$ & STDEV & $\begin{array}{c}\text { Carotenoids } \\
\mathrm{mg} \mathrm{g}^{-1} \mathrm{FM}\end{array}$ & $\begin{array}{c}\text { STDEV } \\
\text { Tomato C. }\end{array}$ \\
Tomato Ir. & 0.557 & 0.009 & 0.291 & 0.023 & 0.848 & 0.049 & 0.146 & 0.014 \\
Carrots C. & 1.224 & 0.085 & 0.339 & 0.021 & 1.120 & 0.114 & 0.228 & 0.027 \\
Carrots Ir. & 1.090 & 0.043 & 0.456 & 0.013 & 1.681 & 0.051 & 0.349 & 0.018 \\
Radish C. & 0.616 & 0.067 & 0.412 & 0.014 & 1.502 & 0.033 & 0.324 & 0.021 \\
Radish Ir. & 0.618 & 0.060 & 0.286 & 0.051 & 0.906 & 0.108 & 0.140 & 0.021 \\
\hline
\end{tabular}

Explanations under Table 2

Studies related to the HPM on the biological objects are a new and dynamic field for scientific research, involving plant biotechnology and microwave engineering. More studies in this area need to be done. However, our study showed that we can expect new promising results in the experiments with HPM and biological objects.

\section{Conclusions}

1. Radish seeds (variety 'Babtų žara') harvested in 2000 and exposed to $9.3 \mathrm{GHz}$ microwaves had higher germination as compared with non-irradiated seeds. High power microwaves (HPM) increased radish germination energy by $6 \%$ in seeds harvested in 2003 .

2. HPM exposure significantly increased the germination energy in tomato seeds (variety 'Viltis') harvested in 2003 and 2008.

3. Microwave exposure significantly increased the germination energy and germination in 8 year-old carrot seeds. The highest carrot seed germination was established at $9.3 \mathrm{GHz}$ microwave frequency under $5 \mathrm{~min}$ exposure.

4. Seed exposure to HPM $(9.3 \mathrm{GHz})$ had a significant positive effect on dry weight of tomato (variety 'Viltis') seedling shoots and on tomato and radish (variety 'Babtų žara') seedling height, but it had a negative influence on carrot (variety 'Vaiguva') seedling height.

5. Seed irradiation with HPM $(9.3 \mathrm{GHz})$ had a significant positive effect on the amount of chlorophyll $a$, chlorophyll $b$, chlorophylls $a+b$ and carotenoids in tomato seedlings (variety 'Viltis') fresh mass, but the opposite effect was determined in carrot (variety 'Vaiguva') seedlings fresh mass.

\section{Acknowledgments}

This research was funded by a grant MIP040/2011 from the Research Council of Lithuania.

Received 20072012 Accepted 13042013

\section{References}

Aladjadjiyan A. 2002. Influence of microwave irradiation on some vitality indices and electroconductivity of ornamental perennial crops. Journal of Central European Agriculture, 3 (4): $271-276$

Aladjadjiyan A. 2010. Effect of microwave irradiation on seeds of lentils (Lens culinaris med.). Romanian Journal of Biophysics, 20 (3): 213-221
Banik S., Bandyopadhyay S., Ganguly S. 2003. Bioeffects of microwave a brief review. Bioresource Technology, 87: 155-15 http://dx.doi.org/10.1016/S0960-8524(02)00169-4

Bobinas Č. 1999. Daržo augalų sèklininkystè. Lithuanian Institute of Horticulture, 108 p. (in Lithuanian)

Crawford A. E. 1977. Phytotoxicity threshold levels of microwave radiation for Trifolium and Medicago seeds. Seed Science and Technology, 5: 671-676

Frohlich H. 1975. The extraordinary dielectric properties of biological materials and the action of enzymes (metastable states in enzymes/coherent vibrations in biological materials). Proceedings of the National Academy of Science USA, 72 (11): 4211-4215 http://dx.doi.org/10.1073/pnas.72.11.4211

Gavrilenko V. F., Zigalova T. V. A. 2003. The photosynthesis guide. Moscow, 256 p. (in Russian)

Gorny R. R. L., Mainelis G., Wlazlo A., Niesler A., Lis D. O., Marzec S., Siwinska E., Ludzen-Izbinska B., Harkawy A., Kasznia-Kocot J. 2007. Viability of fungal and actinomycetal spores after microwave radiation of building materials. Annals of Agricultural Environmental Medicine, 14: 313-324

Hamada E. 2007. Effects of microwave treatment on growth, photosynthetic pigments and some metabolites of wheat. Biologia Plantarum, 2: 343-345 http://dx.doi.org/10.1007/s10535-007-0068-y

Monteiro J. H., Mendiratta S. K., Capitao A. 2008. Effect of microwave fields on the germination period and shoot growth rate of some seeds. International conference Recent Advances in Microwave Theory and Applications. Jaipur, India, p. 792-793 http://dx.doi.org/10.1109/AMTA.2008.4763071

Oprica L. 2008. Effect of microwave on the dynamics of some oxidoreductase enzymes in Brassica napus germination seeds. Sectiunea Genetica si Biologie Moleculara, 9: 99-104

Pachomov A. G. 1998. Current state and implications of research on biological effects of millimeter waves. Bioelectromagnetics, 19: 393-413 http://dx.doi. org/10.1002/(SICI)1521-186X(1998)19:7<393::AIDBEM1>3.0.CO;2-X

Ponomarev L. I., Dolgodvorov V. E., Popov V. V., Rodin S. V., Roman O. A. 1996. The effect of low-intensivity electromagnetic microwave field on seed germination. Proceedings of Timiryazev Agricultural Academy, 2: 42-46 (in Russian)

Racuciu M., Miclaus S. 2007. Low-level $900 \mathrm{MHz}$ electromagnetic field influence on vegetal tissue. Romanian Journal of Biophysics, 17 (3): 149-156

Radzevičius A., Karklelienè R., Bobinas Č., Maročkienè N. 2007. Investigation of reproduction features in bearing 
vegetables. Sodininkystė ir daržininkystè, 26 (2): 45-51 (in Lithuanian)

Ragha L., Seema Mishra S., Ramachandran V., Bhatia M. S. 2011. Effects of low-power microwave fields on seed germination and growth rate. Journal of Electromagnetic Analysis and Applications, 3: 165-171 http://dx.doi.org/10.4236/jemaa.2011.35027

Salama H. M. H., Watban A. A. A., Al-Fughom A. T. 2011. Effect of ultraviolet radiation on chlorophyll, carotenoid, protein and proline contents of some annual desert plants. Saudi Journal of Biological Sciences, 18: 79-86 http://dx.doi.org/10.1016/j.sjbs.2010.10.002

Salles A. A. A. 1999. Biological effects of microwave and RF. International Microwave and Optoelectronics Conference. Rio de Janeiro, Brazil, p. 51-56

Samuolienė G., Sirtautas R., Brazaitytė A., Duchovskis P. 2012. LED lighting and seasonality effects antioxidant properties of baby leaf lettuce. Food Chemistry, 134 (3): 1494-1499 http://dx.doi.org/10.1016/j.foodchem.2012.03.061
Stašelis A. 2007. Influence of direct electromagnetic fields on germination dynamics of carrot seeds, carrot yield and quality. Sodininkystè ir daržininkystè, 26 (4): 201-207 (in Lithuanian)

Stašelis A., Duchovskis P., Brazaityte A. 2004. Impact of electromagnetic fields on morphogenesis and physiological indices of tomato. International Agrophysics, 18 (3): 277 283

Šistek P. 2006. Physical aspects of pulsed microwave absorption in tissue. NATO Security through Science Series, p. 297305

Tylkowska K., Turek M., Blanco P. R. 2010. Health, germination and vigour of common bean seeds in relation to microwave irradiation. Phytopathologia, 55: 5-12

Yanenko A. F., Matsibura A. P., Peregudov S. N., Uniyaka T. L. 2004. Impact of microwave radiation on vegetable biological objects. $14^{\text {th }}$ international Crimean conference Microwave and Telecommunication Technology. Sevastopol, Ukraine, p. 13-17

ISSN 1392-3196 / e-ISSN 2335-8947

Zemdirbyste-Agriculture, vol. 100, No. 2 (2013), p. 179-184

DOI $10.13080 /$ z-a.2013.100.023

\title{
Didelès galios mikrobangų impulsų poveikis: (1) daržo augalų sèklų daigumui ir daigų augimo rodikliams
}

\author{
A. Radzevičius ${ }^{1}$, S. Sakalauskiené ${ }^{1}$, M. Dagys ${ }^{2}$, R. Simniškis ${ }^{2}$, R. Karkleliené ${ }^{1}, \check{C}^{2}$. Bobinas ${ }^{1}$, \\ P. Duchovskis ${ }^{1}$
}

${ }^{1}$ Lietuvos agrarinių ir miškų mokslų centro Sodininkystès ir daržininkystès institutas

${ }^{2}$ Fizinių ir technologijos mokslų centras

\begin{abstract}
Santrauka
Tyrimo metu vertintas didelès galios mikrobangų poveikis augalų sẻklų daigumui ir daigams. Daržovių sèklos buvo veikiamos aukšto dažnio mikrobangomis (ADM). Tyrimo metu daugiausia dėmesio skirta mikrobangų šiluminio poveikio eliminavimui švitinant augalų sèklas, todèl naudoti trumpi, galingi, retai pasikartojantys mikrobangų impulsai. Tyrimo objektas - valgomojo ridikèlio (Raphanus sativus L.) veislès 'Babtų žara', valgomosios morkos (Daucus sativus Rohl.) veislès 'Vaiguva' bei valgomojo pomidoro (Lycopersicon esculentum Mill.) veislès 'Viltis' 2000, 2003 bei $2008 \mathrm{~m}$. derliaus sėklos ir valgomojo pomidoro (Lycopersicon esculentum Mill.) veislès 'Red Cherry' 1980 m. derliaus sèklos. Pirmojo bandymo metu visos sèklos 10 min paveiktos 9,3 GHz dažnio mikrobangomis. Antrojo bandymo metu veislès 'Vaiguva' $2000 \mathrm{~m}$. derliaus morkų sèklos vienu atveju spinduliuotos $9.3 \mathrm{GHz}$ mikrobangomis 5 ir $10 \mathrm{~min}$, kitu atveju mikrobangu dažniai buvo pakeisti i 2,6 ir 5,7 GHz, o švitinimo trukmè - 10 min. Siekiant nustatyti mikrobangų poveikị daigų augimo rodikliams, $2008 \mathrm{~m}$. derliaus pomidorų, morkų ir ridikèlių sẻklos 10 min paveiktos 9,3 GHz dažnio mikrobangomis. Tyrimų metu nustatyta, kad $2000 \mathrm{~m}$. derliaus ridikèlių sẻklos, pašvitintos $9,3 \mathrm{GHz}$ mikrobangomis, pasižymėjo geresniu daigumu, lyginant su nešvitintomis. ADM $2003 \mathrm{~m}$. derliaus ridikẻlių sẻklų dygimo energiją padidino $6 \%$. Esminis teigiamas mikrobangų poveikis užfiksuotas veislès 'Viltis' pomidoru 2003 ir $2008 \mathrm{~m}$. derliaus sèklų dygimo energijai. ADM iš esmès padidino 2003 m. derliaus morkų sėklų daigumą ir dygimo energiją. Didžiausias morkų sėklų daigumas nustatytas jas 5 min paveikus 9,3 GHz mikrobangomis. Sèklų apšvitinimas $(9,3 \mathrm{GHz})$ turèjo esminị teigiamą poveikį pomidorų daigų antžeminès dalies sausosios masės kiekiui ir pomidorų bei ridikẻlių daigų aukščiui, tačiau neigiamai paveikè morkų daigų aukštị. Sẻklų švitinimas ADM $(9,3 \mathrm{GHz})$ turèjo esminę teigiamą įtaką chlorofilo $a$, chlorofilo $b$, chlorofilų $a+b$ ir karotenoidu kiekiui pomidoru daigu lapuose, tačiau morkų daigų lapuose nustatytas priešingas poveikis fotosintezès pigmentų kiekio sumažejimas.
\end{abstract}

Reikšminiai žodžiai: Daucus sativus, fotosintezès pigmentai, Lycopersicon esculentum, Raphanus sativus, švitinimas. 